\title{
Staatsvakken en kerkelijke vakken aan openbare universiteiten 1
}

H M Vroom

Hoogleraar in Godsdienswysbegeerte, Apologetiek en Ensiklopedie van die Godgeleerdheid Vrije Universiteit te Amsterdam

\section{ABSTRACT}

Theology at the state universities in the Netherlands since 1876: State disciplines and church disciplines

In three contributions the organisation of (protestant) theology in the Netherlands since 1876 has been described. In this first part the Dutch law on higher education (1876) is dealt with, its background (especially separation of state and church and equal treatment of religious traditions). This law has established a dual system ("duplex ordo"): "state professors" and "church professors", all paid by the government. Various evaluations of this arrangement are discussed and its recent modification and the mottfs thereof are given. In practice, the theological faculties at the state universities have been mostly reformed faculties.

\section{OPENBARE EN VRIJE UNIVERSITEITEN}

Tot aan de negentiende eeuw was de theologie aan de Nederlandse universiteiten vanzelfsprekend gereformeerd ${ }^{2}$. De historicus Johan Huizinga beschrijft hoe de besturen van de Nederlandse Provinciën zich tot de Franse tijd tamelijk afstandelijk opstelden inzake het bestuur van de hoge scholen en athenea ${ }^{3}$. In de Franse tijd werden de Nederlanden omgevormd tot de "Bataafse Republiek". De Staten-Generaal proclameerden op 4 maart 1795 de "Verklaring van de rechten van de mens en de burger", waarmee godsdienstvrijheid werd geboden. Krachtens het principe van gelijkheid voor de wet rees ook de vraag naar gelijkberechtiging van burgers en hun organisaties, die immers ook voor godsdienstige stromingen zou moeten gelden. De opname in het rijk van Napoleon betekende niet alleen dat kerk en staat gescheiden moesten worden, maar ook dat het hoger onderwijs nauw in het staatsbestel werd opgenomen. De keizer decreteerde op 22 oktober 1811 dat er in Nederland twee academiën gevestigd zouden zijn van de Parijse keizerlijke universiteit, te Leiden en te Groningen. Aan de universiteit van Utrecht was een mindere status toegedacht. Vanuit Parijs werden nauwkeurige regels voor de gang van zaken gegeven ${ }^{5}$. 
Na de Franse tijd ging de Nederlandse overheid de gang van zaken aan de universiteiten nauwkeuriger regelen dan in vervlogen dagen ${ }^{6}$. De universiteiten zouden echte rijksuniversiteiten, staatsinstellingen worden, waar openbaar onderwijs moest worden gegeven. In het spoor van de Verlichting meenden velen dat denken neutraal, algemeen-menselijk en universeel geldig is. De overheid moest (en kon) boven de partijen staan en daarom zou het onderwijs vanwege de overheid neutraal zijn. Vanuit deze optiek was het onvermijdelijk dat de status van de hervormde theologie aan de rijksuniversiteiten vanaf 1814 ter discussie kwam. Het zou maar liefst tot 1876 duren voordat deze kwestie geregeld was, wat niet wil zeggen: goed geregeld was.

Koning Willem I bepaalde op 2 augustus 1815 in het "Organiek Besluit" dat de drie rijkshogescholen (te Leiden, Utrecht en Groningen) vijf faculteiten zouden kennen, waaronder de van "godgeleerdheid tot vorming der kweelingen voor de hervormde godsdienst"?. Wat de theologie betreft bleef alles bij het oude, hoewel de grondwet van 14 augustus 1815 de godsdienstvrijheid vaststelde en mensen met verschillende belijdenis "gelijke aanspraak op het bekleden van waardigheden, ambten en bedieningen" verschafte. De genoemde regeling voor het onderwijs voorzag tevens in subsidiëring van de seminaries voor het hoger onderwijs in de rooms-katholieke godsdienst en verschafte de mogelijkheid van uitkeringen aan luthersen, doopsgezinden en remonstranten voor hun opleiding ${ }^{8}$. Hierbij moet worden bedacht dat de bepaling uit de grondwet van 1815 die een ieder "de volkomen vrijheid van godsdienstige begrippen" bood, ook met het oog op de door de vereniging met (het katholieke) België ontstane toestand werd geformuleerd. Het nieuwe Koninkrijk als geheel was zeker niet hervormd 9 . In 1814 had de Raad van State aan de Koning geadviseerd om een rooms-katholieke theologische faculteit in te stellen te Leiden en een Lutherse te Groningen. In plaats daarvan verkregen de Luthersen een seminarie $^{10}$.

In de periode na de Franse tijd kregen stromingen die niet veel wensten te veranderen grotere invloed. De godsdienstvrijheid was in beginsel dan wel aanvaard, maar de grenzen ervan bleken toen groepen zich uit de staatskerk wilden losmaken: de Afscheiding (1834) ging niet zonder grote weerstand van de zijde van de overheid en de met de staat verbonden Nederlandse Hervormde Kerk. De afgescheiden kerken stichtten in 1854 een eigen theologische school voor hun predikanten te Kampen. In het jaar 1848 brak er in Europa een nieuwe periode aan. De tijd van restauratie scheen voorbij; er waaide een nieuwe wind; het liberalisme zegevierde. In Nederland werd de grondwet herzien. Nu moest ernst 
gemaakt worden met de scheiding tussen kerk en staat en zou er iets gebeuren met de hervormde theologische faculteit aan de rijksuniversiteiten ". Men besloot dat er een nieuwe wet op het hoger onderwijs zou komen, maar het zou nog 28 jaren duren voordat het zover was. Tussen het eerste wetsontwerp en de aanvaarding van de wet lagen 8 jaren. Het hete hangijzer was de theologie. De verschillende bepalingen van de uiteindelijke wet kwamen met wisselende meerderheden tot stand zodat de wet uit een grote reeks compromissen bestond. Huizinga oordeelt dat de wet van 1876 slechts door een "parlementair geschipper zonder weerga" tot stand kwam ${ }^{12}$. De Hoger Onderwijs (HO) Wet 1876 regelde de theologie in wat bekend zou worden als de duplex ordo, te weten een staatsfaculteit voor godgeleerdheid met daarnaast enkele door de kerk aangestelde en door de staat betaalde kerkelijke hoogleraren.

Motieven achter de regeling van de theologie in de Hoger Onderwijswet van 1876 waren: (1) de eenheid van wetenschappelijk onderzoek en opleiding in de zin van voorbereiding tot het bekleden van maatschappelijke betrekkingen - in het geval van de theologie de functie van predikant ${ }^{13}$; (2) de eis van openbaar onderwijs inzake godsdienst (de staatsuniversiteit kan geen hervormde theologie doceren, want zij “is' neutraal ${ }^{14}$ ) en (3) de overheid kan en mag niet in de verantwoordelijkheden van de kerk treden wat betreft de ambtsopleiding. Op de achtergrond stond de wens van de minister tot gelijkberechtiging van verschillende kerkgenootschappen. De remonstrantse minister $J$ Heemskerk zag als enige oplossing dat er geen theologie gegeven zou worden aan de openbare universiteit; anders kwam er niets van neutraliteit en gelijkberechtiging terecht. De Kamer echter besliste anders, en er kwam inderdaad weinig van neutraliteit en gelijkberechtiging terecht.

Zoals gezegd duurde de discussies over de nieuwe HO-wet meer dan acht jaren. Zonder deze discussies nader te bezien kunnen we noch de duplex ordo, noch de stichting van de Vrije Universiteit goed begrijpen. $\mathrm{Bij}$ de wetsvoorbereiding waren meer ministers betrokken, maar het geval wilde dat het eerste wetsontwerp in 1868 werd ingediend door Heemskerk die later weer minister was en in 1876 tot vele compromissen bereid was om de wet aangenomen te krijgen. De ontwerp-wet van 1868 voorzag in de opheffing van de theologische faculteiten. Het geld dat de theologische faculteiten toen kostten, wilde de minister aan de hervormde kerk beschikbaar stellen om in de predikantsopleiding te voorzien. Men bedenke hierbij dat de lutherse en doopsgezinden kerkelijke hoogleraren hadden te Amsterdam, waar de theologische studenten een deel van hun studie konden volbrengen aan het Gemeentelijke Atheneum Illustre. De remonstranten 
zouden hun seminarie in 1873 van Amsterdam naar Leiden overbrengen om aldaar mede gebruik te maken van het universitaire theologische onderwijs ${ }^{15}$. In de memorie van toelichting gaf de minister onder meer de volgende gronden op voor zijn voorstel om de theologie van de universiteit te verwijderen. De huidige faculteit, zo stelde hij, dient niet zozeer tot beoefening van de godsdienstwetenschap alswel tot vorming van "bedienaars der godsdienst". Instandhouding van deze faculteiten ten gunste van een kerkgenootschap strijdt met de grondwet. Terwijl theologische benoemingen voor de regering hete hangijzers zijn, zou een faculteit "boven geloofsverdeeldheid verheven" een "gevaarlijke kweekplaats van scepticisme en materialisme" kunnen worden ${ }^{16}$.

Een andere belangrijke bepaling in de wet, die niet zonder gevolgen zou blijven, was de realisering van de grondwettelijke vrijheid van onderwijs: "het staat ieder nederlands ingezetene, ...elke erkende vereniging en ieder kerkgenootschap vrij ene bijzondere school van hoger onderwijs te openen" ${ }^{17}$. Omdat het kabinet moest aftreden, werd dit wetsontwerp door de Kamer niet besproken, maar intussen waren er wel enkele ideeën gelanceerd die deze en gene aan het denken zetten. Paste de theologie inderdaad niet in de openbare universiteit en de godsdienstwetenschap wel? Bood de stichting van bijzondere universiteiten of een seminarie mogelijkheden? Deze vragen werden al langere tijd besproken, maar door de wetsontwerpen werden het brandende kwesties. De volgende minister, Fock, verving het wetsontwerp door een ander. Hij wilde de indeling van de universiteit in faculteiten laten vervallen en de universiteit in opleidingen organiseren, waarvan de opleiding tot het meesterschap in de godgeleerdheid er één was. De godgeleerdheid gaat zonder dogmatiek: "het Hooger Onderwijs [heeft] niets te maken met de dogmatiek: deze laatste wordt aan de kerkgenootschappen overgelaten. Maar aan onze Hoogescholen moet een vrij theologisch wetenschappelijk onderwijs behouden blijven" 18 .

De discussie rond de HO-wet 1876 laat zich alleen goed verstaan tegen de achtergrond van de kerkelijke richtingenstrijd in de vorige eeuw. In de elitaire Nederlandse samenleving hadden de liberalen in het parlement grote invloed. Er was geen algemeen kiesrecht. In de synode was in het midden van de negentiende eeuw de moderne richting sterk, maar in de periode waarin de invoering van de $\mathrm{HO}$-wet speelde was dat niet speciaal meer het geval. De Groninger richting was in Kuyper's oog niet rechtzinnig genoeg, maar in de periode waarom het hier gaat, was de Groninger faculteit gematigd orthodox. De Utrechtse faculteit was tegen het midden van de negentiende eeuw de meest traditionele van de drie en ook later worden er veel orthodoxe theologen aangesteld ${ }^{19}$. De organisatie van de 
Nederlandse Hervormde Kerk was na de Franse Tijd bij Koninklijke Besluit geregeld, maar in 1869 was de band tussen kerk en overheid losser gemaakt dan tevoren ${ }^{20}$. Vele orthodoxen wantrouwden de hervormde synode - een wantrouwen dat bij de benoeming van de nieuwe kerkelijke hoogleraren na 1876 nog versterkt zou worden. Kuyper stelt dat het modernisme in de kerk heerste - maar daartoe rekent hij dan wel de meesten van wie het niet met hem eens zijn ${ }^{21}$. Hij is één van de meest geharnaste tegenstanders van de meerderheid van de synode. Zijn bezwaren gelden vooral de wijze waarop de kerk is ingericht. Ten gevolge van de door de overheid opgelegde organisatie van de kerk heeft de orthodoxie z.i. te weinig invloed. Hij voorziet dat de stichting van hervormde seminaries de niet-orthodoxe stromingen in de kerk nog verder in het zadel zullen helpen: "De partij in de Kerk, die door haar ongereformeerde natuur feitelijk zich buiten die Kerk plaatst, maar die door een voor haar bij uitstek gunstige organisatie, het roer heeft weten in handen te krijgen, zou dan, gerugsteund door de geldmacht van de Staat, de algemeene seminarieën misbruikt hebben tot kweekscholen voor haar Kerkverwoestenden geest"22.

Kuyper is niet alleen tegen seminaries, ook de gedeeltelijke theologische opleiding van het ontwerp-Fock vindt geen genade in zijn ogen. Diens visie op godsdienstwetenschap past wel de modernen maar niet de orthodoxen. Het ontwerp-Fock (dat in bepaalde opzichten sterk gelijkt op de later vastgestelde duplex ordo) verwerpt hij als een vermomde Theologische faculteit ten behoeve der moderne Theologie. De vrijzinnige richting is tevreden met godsdienstwetenschap, los van kerk en dogmatiek. Kuyper meent dat in deze vrijzinnige opvatting van theologie besloten ligt "het plaatsen van het Christendom op één lijn met alle overige godsdiensten, al gunt men het op die lijn ook de uitnemendste plaats" ${ }^{23}$. Kuyper wijst de staatsmacht af, zowel in de regeling der Hervormde Kerk als ook in de regeling aangaande de openbare, neutrale theologie. In februari 1870 vraagt hij om een "vrije universiteit" met een bloeiend theologisch leven ${ }^{24}$. De aanvaarding van de wet op het Hoger Onderwijs 1876 met zowel vrijheid van hoger onderwijs als de duplex ordo van theologie zou inderdaad in 1880 tot de oprichting van de Vrije Universiteit leiden. Vrij is hier primair vrijheid van staatsdwang, zowel in de kerk als aan de universiteit. De wet op het Hoger Onderwijs 1876 heeft echter niet alleen een staatsrechtelijke maar ook een kerkelijke achtergrond. De tegenstellingen in de vaderlandse hervormde kerk hebben een grote rol gespeeld in de aanvankelijke inrichting van de duplex ordo en ook in de stichting van de Vrije Universiteit.

De wet $1876 \mathrm{kwam}$ tot stand in een periode waarin het modernisme aan de rijksuniversiteiten tamelijke invloed had. In de "christelijke cultuur" 
waarin men leefde, meenden sommigen zuiver neutraal te kunnen vaststellen wat de christelijke waarheid was. De Leidense systematisch theoloog $\mathbf{J}$ H Scholten, bij wie zowel A Kuyper als H Bavinck gepromoveerd waren ${ }^{25}$, vond dat de universitaire theologie geen dienaresse van de kerk mocht zijn en dat de academie garant moest staan voor vrij onderzoek. Intussen werd ook het openbare, universitaire deel van de theologie door de christelijke cultuur bepaald, zoals we zien als Scholten aan zijn beschouwing over de duplex ordo toevoegt dat hij in het christendom "de zuiverste uitdrukking" ziet "van het godsdienstig leven, die op historisch gebied zich voordoet"; hij bedoelde daarmee de godsdienst zoals die in het menselijke hart lag, zoals Jezus zelf bedoelde, en niet wat mensen er later van hebben gemaakt ${ }^{26}$. In heel de cultuur van de negentiende eeuw is de superioriteit van de westerse cultuur vanzelfsprekend. Men denkt in termen van vooruitgang en helpt volkeren in minder beschaafde culturen zich tot hoger peil te ontwikkelen. Binnen deze cultuur leiden ook de onderzoekingen van de godsdienstwetenschap en de studies in de godsdienstwijsbegeerte tot instemming met de waarheid van het christendom, zij het dat het voor de modernen ondogmatisch en vrijzinnig christendom is, dat slechts één offer kent: het aan God gewijde hart ${ }^{27}$. Een eeuw later zal blijken dat de godsdienstwetenschap zich uit dit vrijzinnige paradigma heeft losgemaakt, zodat godsdienstwetenschap en theologie uiteengroeien. Maar laten we niet tezeer op de ontwikkelingen vooruitlopen en eerst de duplex ordo en de receptie ervan bezien, zoals die beschreven is door $O$ de Jong en $G E$ Meuleman28.

\section{DE “DUPLEX ORDO” VAN 1876}

\subsection{De totstandkoming van de wet}

Toen minister Heemskerk eind 1874 voor een tweede ambtstermijn aantrad had juist een commissie van rapporteurs uit de Tweede Kamer aanbevolen om de vakken der godsdienstwetenschap bij de Faculteit der Letteren te voegen. Heemskerk volgde deze suggestie en stelde voor dat er in de Faculteit der Letteren een doctoraat in de godsdienstwetenschap en wijsbegeerte mogelijk zou worden gemaakt. Hij vond echter de hervormde synode op zijn weg, want deze wilde niet afzien van de universitaire opleiding tot predikant ${ }^{29}$. De Leidse faculteit pleitte voor vrije studie van religie inclusief de waarheidsvraag, zoals we al zagen. De Utrechtse faculteit klopte net als de Leidse bij de minister aan, maar dan met het verzoek de complete godgeleerdheid te handhaven: theologie was onbestaanbaar zonder dogmatiek. Godsdienstwetenschap gaat over geloof van 
mensen, godgeleerdheid over God ${ }^{30}$. Daarbij vatte men godsdienstwetenschap op als een beschrijvend vak, anders dus dan de Leidse faculteit het zag31. Uiteindelijk werd besloten dat er een faculteit voor godgeleerdheid zou komen, maar wel los van de Hervormde Kerk en zonder leerstellige en practische godgeleerdheid ${ }^{32}$. De kamerleden die voorstelden om deze twee vakken te schrappen, beriepen zich op de scheiding van kerk en staat ${ }^{33}$ en op wetenschapstheoretische overwegingen ${ }^{34}$. De minister, die zelf niet in neutraliteit in deze faculteit geloofde ${ }^{35}$, had de theologie als wetenschap omtrent het goddelijke liever uit de wet geschrapt. Het was z.i. niet goed denkbaar dat een hoogleraar bij dit onderwerp zou nalaten over het meest wezenlijke van zijn vak te spreken, zodat bij de godgeleerdheid altijd ook de dogmatiek wel zou terugzien ${ }^{36}$. Hij meende blijkbaar dat dogmatische stellingnames aan de theologie eigen zijn, zodat men ze niet uit het openbaar onderwijs kan verwijderen zolang er theologie wordt gedoceerd.

Vaak wordt gezegd dat de theologische faculteit met de invoering van de duplex ordo is vervangen door een faculteit voor godsdienstwetenschap. O J de Jong meent echter dat dit niet het geval is; de wetgever liet dogmatiek en praktische theologie aan de kerk over, die er graag zeggenschap over verkreeg ${ }^{37}$. G E Meuleman oordeelt dat de wet destijds ruimte liet om theologie te beoefenen in gebondenheid aan de openbaring van $\mathrm{God}^{38}$. De feitelijke uitwerking van de wet werd door de opvattingen van de aangestelde mensen bepaald.

De vele compromissen die aan de wet ten grondslag hebben gelegen, maken het moeilijk om al teveel over de bedoeling van de wetgever te zeggen buiten wat uitdrukkelijk in de tekst van de wet is bepaald. Duidelijk zijn de principes die aanleiding gaven tot de nieuwe wet: de scheiding van kerk en staat, het streven naar gelijkberechtiging van andersdenkenden, en een verwerping van confessionele theologie aan de openbare universiteit ten gunste van de vrijheid van de individuele onderzoeker (die vervolgens best gelovige mocht zijn). Duidelijk is echter ook dat deze principes in de duplex ordo niet zijn gerealiseerd: in feite bleef de theologische faculteit van de openbare universiteit een hervormde faculteit en werd de gelijke bekostiging van de roomskatholieke en gereformeerde opleidingen pas in 1970 gerealiseerd.

\subsection{De inhoud van de wet}

Dan nu de inhoud van de wetgeving. De HO-wet 1876 schrijft voor dat aan de Faculteit der Godgeleerdheid de volgende vakken gegeven zullen worden: encyclopedie, geschiedenis van de leer aangaande God, geschiedenis der godsdiensten in het algemeen, de geschiedenis van de israëlitische 
godsdienst, de geschiedenis van het christendom, de israëlitische en de oud-christelijke letterkunde, de uitlegging van het Oud en Nieuw Testament, de geschiedenis der leerstellingen van de christelijke godsdienst, de wijsbegeerte van de godsdienst en de zedekunde. Voorgesteld waren ook de leerstellige en practische godgeleerdheid maar die zijn geschrapt en aan de kerk overgedragen ${ }^{39}$.

In de praktijk hield de wet in (gerekend naar een studieduur van ongeveer zes jaren, zoals in elk geval sedert de jaren zestig van de twintigste eeuw het geval is) dat de student in de theologie vier jaren aan de openbare faculteit studeerde en daarna twee jaren bij kerkelijke hoogleraren. Op het gebied van dogmatiek, praktische theologie, missiologie en apologetiek kon men geen doctoraal examen afleggen, maar wel een dissertatie voorbereiden. Voor de studie van deze theologische disciplines leverde dit uiteraard grote problemen op.

Bij de wetsherziening in 1921 heeft men de regeling uit 1876 vrijwel geheel intact gelaten. Wat betreft de kerkelijke instellingen tot opleiding van leraren voor kerkgenootschappen wordt in de HO-wet 1921 bepaald dat ze, als zij in 1903 geld ontvingen, dat ook verder zullen verkrijgen en dat de Hervormde kerk een tegemoetkoming kan krijgen als ze een of meer leerstoelen of scholen van hooger onderwijs vestigt. Vastgesteld wordt dat studenten aan deze kweekscholen toegang hebben tot de lessen van docenten aan de rijksuniversiteiten, voor de helft van het geld ${ }^{40}$. Bij de discussies voorafgaand aan deze wet beschouwde men de godsdienst als object van de godgeleerdheid; net als het recht en de letteren rechtvaardigt dit object een eigen faculteit. Indien tot herkaveling van faculteiten moest worden overgegaan, zou men er de voorkeur aan geven de wijsbegeerte uit de letterenfaculteit los te maken en met de godgeleerdheid te combineren ${ }^{41}$.

\subsection{De interpretatie van de wet}

De beoordeling van de HO-wet 1876 werd aan orthodoxe kant in sterke mate bepaald door een achteraf onverstandig beleid vanwege de hervormde synode. Naar het oordeel van de kerkhistoricus De Jong veroorzaakte de synode de grootste ergernis ${ }^{42}$. Zoals we zagen voorzag de wet in de aanstelling van kerkelijke hoogleraren vanwege de hervormde kerk, die met gebruikmaking van de universitaire voorzieningen aanvullend onderwijs in de leerstellige en practische godgeleerdheid konden verzorgen. De Leidse faculteit adviseert één kerkelijke leerstoel dogmatiek in te stellen. "Utrecht en Groningen denken aan twee zetels". Tegenstanders van de duplex ordo pleiten voor "vrije godgeleerde scholen". Uiteindelijk vergt de kerk veel vakken - alsof die allemaal van de universiteit verwijderd zijn! -, maar de 
regering stelt er zes beschikbaar, voor elke faculteit twee. Als er in 1878 (mede vanwege een weigering) van de zes maar één leerstoel naar een orthodox theoloog gaat, ervaart de orthodoxie dit als een achterstelling en is de breuk tussen de hervormde synode en een vleugel van de gereformeerde orthodoxie niet meer te helen. De Jong oordeelt hard: "Niet de wet maar de partijdige handelwijze van de synode is het geweest die contribuanten heeft gekweekt voor de 'vereniging voor hoger onderwijs op gereformeerde grondslag' en die Kuypers principiële kritiek op de wet een veel grotere klankbodem gaf" 43 .

Ik denk dat men de duplex ordo zoals die tot stand is gekomen binnen de feitelijke machtsverhoudingen, een laat-christelijke "oplossing" voor de scheiding kerk-staat in het openbare onderwijs mag noemen. Immers, binnen de "christelijke cultuur" staan godsdienstwetenschap en godsdienstwijsbegeerte niet werkelijk neutraal tegenover het christendom. Voor vrijzinnige theologen lag dit wel anders dan voor orthodoxe, al bleek de wet in de praktijk ruimte te bieden voor een "gewone hervormde faculteit" - zoals die na verloop van tijd ook tot stand kwam.

De wet is altijd verschillend uitgelegd en toegepast. In feite blijven de verschillende visies van de mensen uit Utrecht, Leiden en de kring rond de later opgerichte Vrije Universiteit - die elk destijds hun lijnen naar parlementsleden hadden - het beeld nog jarenlang bepalen, totdat na enkele decennia de theologie weer als integrale (hervormde) theologie beoefend wordt.

Aanvankelijk werd de wet uiteraard zeer verschillend boordeeld. Voor de Leidenaar J H Scholten impliceerde scheiding tussen kerk en staat dat er een tweeledige verantwoordelijkheid bestaat, waarin de kerk vrij is om te besluiten de academische theologie te gebruiken of niet ${ }^{44}$. Voor de Leidenaren telden de kerkelijke vakken niet als deel van de echte theologische wetenschap ${ }^{45}$. De Utrechtse faculteit heeft de duplex ordo minder dan de Leidse vanuit de gedachte van neutrale wetenschap uitgelegd. Hier werd de duplex ordo zo geïnterpreteerd dat de overheid de verantwoordelijkheid voor bepaalde centrale theologische vakken aan de kerk overliet. Deze vakken maken, in deze visie, wel deel uit van de theologische wetenschap. J H Gunning speelde met de gedachte van een vrije universiteit maar meende toch dat Nederland als "protestantse staat" ruimte heeft voor de handhaving van de faculteit der godgeleerdheid. Hij interpreteerde de duplex ordo als uitdrukking van dit nationaal-protestants karakter van het land $^{46}$. Anderzijds schreef F E Daubanton, die in 1903 kerkelijk hoogleraar te Utrecht zou worden voor de bijbelse en praktische theologie, in 1884 een verhandeling waarin hij de duplex ordo scherp kritiseerde. Het 
staatsdeel is geen echte godsdienstwetenschap en de theologie is niet compleet: "Een lichaam zonder hoofd, zonder handen en voeten - een romp" 47 .

In de kring rond Kuyper overheerste de visie dat de wet van 1876 de naam godgeleerdheid had gehandhaafd, maar in feite toch de theologie in een faculteit voor godsdienstwetenschap had omgezet. Op de achtergrond stonden Kuypers ongeloof in neutrale wetenschapsbeoefening, Bavincks verzet tegen de door de Leidse hoogleraar Rauwenhof bepleitte secularisatie van de theologie ${ }^{48}$ en beider pleidooi voor een theologie die zich integraal naar Gods openbaring richt.

In 1901-5 kwam de duplex ordo weer in discussie. Als minister van binnenlandse zaken verdedigde Kuyper namelijk een herziening van de HO-wet op twee punten, ten eerste de opname van de polytechnische school te Delft in het hoger onderwijs en ten tweede de verlening van effectus civilis aan bijzondere universiteiten. De wet van 1876 had weliswaar vrijheid van onderwijs geboden, en op die noemer was de Vrije Universiteit gesticht, maar omdat de bijzondere universiteiten geen officiële erkenning als opleiding voor maatschappelijke taken (effectus civilis) verkregen, moesten bijvoorbeeld de studenten van de juridische faculteit van de Vrije Universiteit alle examens aan een openbare universiteit overdoen ${ }^{49}$. Bij hervormde predikant-kamerleden kwam de pijn over de duplex ordo boven. De Vrije Universiteit met haar echte theologische faculteit zou door de wetswijziging verder in het zadel geholpen worden, terwijl de hervormde kerk het met minder moest doen. Het kamerlid Schokking - zelf de achtste promovendus van de Vrije Universiteit - vergde dat de regering de theologische faculteit aan de rijksuniversiteiten zou restaureren ${ }^{50}$. Kuyper stemde met hem in dat de theologische faculteit aan de openbare universiteit in feite een faculteit voor godsdienstwetenschap was geworden en dat die bij een komende reorganisatie weer in een theologische faculteit veranderd zou moeten worden, maar stelde dat dit bij deze wetswijziging niet geregeld kon worden 51 . Sterke protesten tegen deze gelijkstelling van de Vrije Universiteit met de openbare universiteiten kwamen er van de kant van hervormde predikanten, die op een dag in maart 1904 te Utrecht een protestbijeenkomst belegden waaraan volgens de berichtgeving maar liefst 125 predikanten deelnamen ${ }^{52}$. Uiteindelijk werd de gewijzigde HO-wet in 1905 aanvaard ${ }^{53}$.

Op den duur werd de theologische faculteit aan de rijksuniversiteiten meer en meer als een integrale theologische faculteit opgevat. In de "christelijke cultuur" was het staatsdeel natuurlijk geen brede godsdienstwetenschap, maar bestudering van het christendom. De studenten bestudeerden 
immers hoofdzakelijk joodse en christelijke geschriften en niet uitvoerig de Koran en zo ook niet primair de geschiedenis van het boeddhisme of hindoeïsme maar die van het christendom. Op een enkele uitzondering na benoemde de overheid geen athesten maar meelevende hervormde hoogleraren. Het was, kortom, lange tijd meestal een hervormde faculteit met rijksbekostiging en benoeming van de staatshoogleraren door de (neutrale) overheid $^{54}$. We vinden deze situatie beschreven in de inleiding op een bundel van de Groninger hoogleraren over al de theologische vakken uit 1946. Van Oyen schrijft dat de in de wet aangegeven scheiding tussen de zuiver-wetenschappelijke en dogmatisch-kerkelijke vakken wankel is geworden "en de praktijk der theologische faculteiten sedert langen tijd zich niet meer op het standpunt kon stellen, dat zij zich louter met godsdienst-verschijnselen bezig hield, zonder tegelijk haar getuigenis te doen horen" 55 . Krasser is nog wat Hendrik Kraemer in 1959 zegt. Het is zijn taak om binnen de staatsvakken de godsdienstwetenschap te geven, en welk vak past er beter binnen het staatsdeel van de godgeleerdheid? Kraemer echter voelt zich geroepen om de plaats van de godsdienstwetenschappen in de theologische faculteit te verantwoorden. Voor de duplex ordo heeft hij geen goed woord over: het is een anomalie, een "lam" geval, al valt de praktijk mee, want "ieder doet wat goed is in zijne theologische of niet-theologische ogen" 56 . H Berkhof was hem in zijn kritiek op de duplex ordo al voorgegaan: theologie dient integrale theologie te zijn ${ }^{57}$. Intussen bestond er veelal een goede samenwerking tussen de rijksdocenten en de kerkelijke docenten. Dankbaar en M de Jonge redigeerden in 1965 een "Inleiding tot de theologische studie" vanwege de vier rijksfaculteiten met inleidingen op alle vakgebieden van de theologie. De kerkelijke hoogleraar Berkhof schrijft de bijdrage over "bijbelse theologie", de universitaire docenten Hulst en Sevenster de artikelen over de vakken van het Oude en Nieuwe Testament. Naast een bijdrage over de fenomenologie van de godsdienst staat een inleiding over apostolaat. Openlijk schrijven de kerkhistoricus Dankbaar en de latere Leidse nieuwtestamenticus $M$ de Jonge dat intussen

"Wel algemeen wordt ingezien, dat de scheiding van vakken die de wetgever in 1876 voor ogen stond - strikt wetenschappelijke enerzijds en dogmatische en practische vakken anderzijds - onmogelijk ten volle doorgevoerd kan worden. Iedere theologische discipline komt krachtens haar aard voor vragen te staan, die met geloof, kerk en belijden te maken hebben; omgekeerd kunnen de dogmatische en practische vakken het literair-exegetisch en kritisch-historisch onderzoek en het algemeen-systematische denken niet ontberen" 58 . 
Door de ontwikkelingen in de wetenschapsleer is er, anders dan in de negentiende eeuw, een diepe wederzijdse erkenning van elkaars onderscheidene wetenschapsbeoefening gekomen tussen rijkshoogleraren en kerkelijke hoogleraren - aan de gemeentelijke universiteit van Amsterdam hebben enige kerkelijke hoogleraren tevens een benoeming aan de openbare faculteit ${ }^{59}$.

Hoezeer men rond 1876 en in de jaren daarna ook over de juiste interpretatie van de Hoger Onderwijswet 1876 van mening verschilde, uiteindelijk is het effect van de wet wel geweest dat bepaalde vakken uit de theologie als voluit wetenschappelijk gelden en andere als minder wetenschappelijk, want vooringenomen en confessioneel bepaald. De gedachte dat wetenschap neutraal moet zijn en dat er aan de openbare universiteit en in heel het openbaar onderwijs - geen levensbeschouwelijk gekleurde vakken mogen bestaan, is in Nederland sterker verbreid dan in sommige andere landen.

De betrekkelijke vrede tussen de staatshoogleraren en de kerkelijke heeft na de jaren zestig schade opgelopen. De ongelijke positie van de kerkelijke vakken in de duplex ordo bleef protest oproepen, zoals bijvoorbeeld dat van Nijk en Sperna Weiland in 196960. In de praktijk werd de achterstelling wat verzacht en werd de duplex ordo niet als een rigide scheiding opgevat, maar zoals we nog zullen zien rees daartegen rond 1976 scherp verzet. De godsdienstwetenschap heeft zich in de eeuw die sedert 1876 is verstreken sterk ontwikkeld; veel beoefenaren van dat vak menen dat zij neutraal moeten zijn en geen confessioneel bepaalde standpunten mogen verdedigen. Door secularisatie en levensbeschouwelijk pluralisme wordt steeds minder vanzelfsprekend dat staatshoogleraren meelevende leden van de hervormde kerk zijn. De status van de theologie wordt door sommigen in twijfel getrokken, soms ook aan christelijke zijde ${ }^{61}$. Godsdienstwetenschap gaat zich sedert de jaren tachtig steeds meer zien als tegengesteld aan de theologie, schrijft Van den Broek ${ }^{62}$. Anderen trachten deze visie op wetenschap te weerleggen. Dogmatici van Leiden en Utrecht bepleiten een integrale beoefening van de theologie die haar uitgangspunt in Gods openbaring heeft. Berkhof spreekt zowel bij zijn aantreden als zijn vertrek over "God als voorwerp van wetenschap"63. Zijn opvolger deelt zijn mening64. De Knijff pleit voor een simplex ordo van integrale theologie en wil een plaats inruimen voor humanisten, joden, moslims en wie verder nog staan te dringen voor de poort, maar het is hier niet de plaats om daarop in te gaan 65 . 
Ten gevolge van de secularisatie en de verdere uitbouw van de godsdienstwetenschappen ontstond er, zoals gezegd, opnieuw spanning tussen de kerkelijke en de staatsvakken ${ }^{66}$. Toen de kerkelijke hoogleraren zich te Leiden in 1976 een betere bestuurlijke positie hadden verworven dan de wet toestond, moesten zij het ontgelden. Onder de niet voor misverstand vatbare titel 100 jaar "Uit Egypte" verschenen pleidooien om de universitaire faculteit van kerkelijke aangroeisels te ontdoen ${ }^{67}$. De betrekkelijk gelijke behandeling van kerkelijke hoogleraren werd ongedaan gemaakt ${ }^{68}$. Sommigen wilden een striktere scheiding van kerkelijke en staatsvakken. De ongelijke behandeling van kerkelijke hoogleraren en staatshoogleraren kon binnen de bestaande regeling dus niet ongedaan worden gemaakt. Het uiteindelijk effect van de onvrede over de achterstelling van kerkelijke hoogleraren - alleen bijvak- en geen hoofdvak- studenten, minder wetenschappelijke assistenten, minder faciliteiten - was echter dat de hervormde kerk samen met een aantal kleinere kerkgenootschappen stappen ondernam om de zaken beter te regelen.

De directe aanleiding tot de aanpassing van de duplex ordo was dat de Verkenningscommissie Godgeleerdheid in 1989 vaststelde dat de kerkelijke vakken achtergesteld waren vergeleken bij de staatsfaculteit en de bijzondere theologische faculteiten ${ }^{69}$. Men wees erop dat zij over minder medewerkers en faciliteiten beschikten dan de collega's. De kerkgenootschappen kwamen vervolgens op voor de belangen van dogmatiek, christelijke ethiek, missiologie en praktische theologie. Men dreigde een eigen Hervormde Theologische Universiteit te stichten, een hervormde pendant van de Gereformeerde Theologische universiteit te Kampen, die colleges zou kunnen inkopen bij de rijksuniversiteiten (maar dat, als daartoe aanleiding bestond, uiteraard ook kon nalaten $)^{70}$. Indien dit initiatief werkelijkheid zou zijn geworden, dan zou het intitatief wat betreft de financiering van de staatsvakken voor een deel in handen van de kerk zijn gekomen, en dus de macht van de universiteit naar de kerk verschoven.

De minister zegde meer geld voor de kerkelijke opleiding toe en raadde de universiteiten en de kerken aan met elkaar over de achterstelling van de kerkelijke vakken in het studieprogramma te spreken. Na rijp beraad bleken de rijksuniversiteiten bereid om een betere regeling voor de kerkelijke docenten te aanvaarden. De vier universiteitsbesturen bereikten op 8 november 1991 overeenstemming met een zevental kerkgenootschappen over de nieuwe orde. Het "Akkoord op hoofdlijnen" spreekt uit:

"dat de theologische encyclopedie wordt gevormd door een geheel van vakken die enerzijds vanwege de universiteit en anderzijds 
vanwege de kerken worden onderwezen. $\mathrm{Er}$ is een principiële wetenschappelijke gelijkwaardigheid van alle vakken".

De regeling houdt in dat krachtens de scheiding van kerk en staat de verantwoordelijkheid voor de staats- en de kerkelijke vakken gescheiden blijft. De studenten kunnen zich voortaan specialiseren in de kerkelijke vakken. Kerkelijke hoogleraren kunnen een tweede benoeming verkrijgen in de staatsfaculteit - in Groningen en Utrecht wordt deze praktijk van de Universiteit van Amsterdam overgenomen ${ }^{71}$. Het uiteengroeien van theologie en godsdienstwetenschap vinden we terug in de gewijzigde naam die de Groninger faculteit voert: Faculteit voor Godgeleerdheid en Godsdienstwetenschap. Een voorname verandering betreft ook de programmering van de studie; de kerkelijke vakken komen niet meer na afronding van de andere, maar kunnen naast de andere vakken worden bestudeerd. Hiermee is de duplex ordo niet opgeheven, maar de achterstelling is verzacht. Wel kan men zich afvragen of met de nieuwe regeling de scheiding van de staats- en kerkelijke vakken wel helder wordt gehandhaafd. Kan men deze scheiding niet beter laten vervallen en de mogelijkheid van integrale theologische faculteiten benutten?

De discussie rond de duplex ordo overziende, moet m.i. toch worden geconstateerd dat het een zorgenkindje blijft. In feite is het een laatchristelijke oplossing, die werkt zolang in de staatsfaculteit mensen doceren die het christendom een goed hart toedragen. Door de secularisatie en pluralisering van de cultuur zal de theologische studie zich steeds duidelijker onderscheiden van een godsdienstwetenschappelijke opleiding, waarin veel meer godsdiensten dan het christendom ruime aandacht moeten krijgen. Daarmee zal de vraag steeds luider worden of er niet een andere taakverdeling tussen de universiteit en de kerken en andere religieuze gemeenschappen kan worden gevonden dan de duplex ordo, waarbij ook de omvang van de kerkelijke en de staatsvakken anders kan worden.

Een voordeel van de duplex ordo is dat de theologische studie in een brede universiteit is ingebed72. De duplex ordo draagt echter de kiem van mislukking in zich doordat ze geen plaats heeft voor de bestudering van de Heilige Schrift als openbaring. De bestudering van de Heilige Schrift als getuigenis van God met oog op kennis van God is immers niet pas de taak van de kerkelijke vakken maar al van de bijbelwetenschap. Hoe kan een christen-exegeet die de teksten van het Oude en Nieuwe Testament leest, eraan voorbijgaan dat zij er zelf aanspraak op maken boodschap van godswege te zijn? De bijbelwetenschapper "die aan deze "zelfimterpretatie" van de teksten voorbijgaat, voldoet niet aan zijn wetenschappelijke opdracht, de teksten uit te leggen - ...principiëel en methodisch', schrijft de dogmaticus 
De Knijff ${ }^{3}$. Zo zal men ook de waarheidsaanspraken van de Koran niet buiten beschouwing mogen laten. Godsdienstwetenschap loopt, zo gezien, uit op een welwillende maar tegelijk kritische dialoog ${ }^{74}$.

Het proces van bijbeluitleg, historisch onderzoek en interpretatie van filosofieën kent een fase waarin men probeert de teksten uit te leggen binnen de horizon van het verleden. De godsdienstwetenschap bewaart, zo zeggen velen, een dergelijke afstand tot het voorwerp van onderzoek, waarbij men zich van oordelen onthoudt. Godsdienstwetenschap zoekt niet naar kennis van God maar naar kennis van wat mensen over "God" zeggen en dus naar getuigenissen van mensen die zeggen dat zij God hebben ontmoet. Dit impliceert dat de Bhagavadgita in de godsdienstwetenschap (en dus in de staatsfaculteit?) niet anders wordt uitgelegd dan de bijbel. Het geloof dat de bijbel anders met God verbonden is dan de Bhagavadgita mag een rol spelen in de dogmatiek maar officieel niet in de godsdienstwetenschap. Aan een openbare theologische faculteit bestaat geen "schriftgebonden" of door kerk en dogma bepaalde wetenschap, schrijft Van den Broek $^{75}$. Intussen kent hij aan de systematische theologie wel de spilfunctie in de hele theologie toe; zij heeft "een systematiserende en integrerende functie"76. Deze functie heeft ze juist doordat er in de systematische vakken wordt nagedacht over de boodschap van de teksten en de inhoud van het geloof. Maar, zo moet men zich dan toch afvragen, waarom ligt wat de theologie integreert en tot eenheid brengt - de vraag naar de boodschap van de Schriften en de waarheid over God - buiten de staatsfaculteit?

Het staat wel vast dat het laatste woord rond de duplex ordo nog niet is gesproken. Niet aan alle faculteiten hebben de kerkelijke hoogleraren een tweede aanstelling in de rijksfaculteit verkregen. De feitelijke uitwerking van de programmering van de beide soorten vakken verschilt. De ene staatsfaculteit zal zich welwillender tegenover de kerkelijke opleiding opstellen dan de andere. Op de achtergrond staan de verschuivingen in onze cultuur, vooral de pluralisering en secularisering. De duplex ordo in huidige vorm zal wel niet het eindstadium van de ontwikkeling zijn. Daarom wordt er nagedacht over de manier waarop de bezinning op geloof in een plurale cultuur georganiseerd moet worden. De nieuwe wet op het Hoger Onderwijs en Wetenschappelijk Onderzoek van 1992 laat veel meer vrijheid aan de universiteiten om zelf opleidingen te programmeren. De overheid treedt veel meer terug en beoordeelt het universitaire beleid vooral op doelmatigheid. De universiteiten stellen zelf visitatiecommissies in voor onderwijs danwel onderzoek in die de facultaire programma's, mede gelet op internationale usances en normen, vergelijken en beoordelen. Het lijkt mij dat de universiteiten, nu zij zoveel jaren na de 
Franse tijd wat meer vrije universiteiten worden dan rijksuniversiteiten, de vrijheid hebben de dingen te regelen zoals het hun zelf verantwoord en zinvol voorkomt. De overheid kan volstaan met het bewaken van de gelijkberechtiging van de diverse levensbeschouwelijke groeperingen - maar daarop kom ik terug.

\section{NOTAS:}

1 Hierdie artikel is geskryf binne die kader van 'n besoek van prof $H$ M Vroom aan die Departement Dogmatiek en Christelike Etiek in die Fakulteit Teologie (Afdeling B) van die Universiteit van Pretoria as navorsingsgenoot van prof $\mathrm{C} \mathrm{J}$ Wethmar.

2 Ik dank mijn collega dr $\mathrm{J}$ Vree, kerkhistoricus aan de Vrije Universiteit te Amsterdam hartelijk voor zijn bereidwilligheid deze bijdragen te lezen en van commentaar te voorzien. Dankzij zijn deskundigheid inzake met name de negentiende eeuwse Nederlandse theologie heb ik vele verfijningen kunnen aanbrengen. De Synode van Dordt heeft in de 163ste zitting wensen geformuleerd voor een kerkelijke medeverantwoordelijkheid bij benoemingen in de theologische faculteiten, zoals goedkeuring van voordrachten voor benoeming door de synode, die door de overheid echter niet zijn gerealiseerd. Men bedenke dat de kerk tucht kon oefenen over hoogleraren die lid van de kerk waren. Zie D Donner (red), Acta of Handelingen der Nationale Synode ... te Dordrecht, Leiden ca. 1885, 163ste zitting, post-acta, 940.

3 J Huizinga, "Het bestuur der rijksuniversiteiten", in: J Huizinga, Verzamelde werken, deel VIII, Haarlem 1951, 17; "Geschiedenis der universiteit, gedurende de derde eeuw van haar bestaan", in: Huizinga, a w, 44.

4 A Huussen (jr), "De gelijkstelling der Joden met andere Nederlandse burgers in 1796", in: R Kranenborg \& W Stoker, Religies en (on)gelijkheid in een plurale samenleving, Apeldoorn 1995, 150.

5 B J L de Geer, "De regeling van het hooger onderwijs in Nederland in 1814", Nieuwe Bijdragen van rechisgeleerdheid en Wetgeving 1869, 213. Zie Huizinga, $a w, 4 l v v$. Huizinga schrijft: "Wat het academisch onderwijs zelf betreft, geen grooter tegenstelling was denkbaar dat tusschen het régime der oude verderlandsche hoogescholen, waar de vrijheid aan bandeloosheid grensde, en de dwingende, vaak kleingeestige voorschriften, die thans de studie en het studentenleven regelden. De stof van alle colleges was voorgeschreven..., alles was tot in bijzonderheden vastgesteld" ( $p$ 44).

$6 \quad$ Huizinga, $a w, 56$.

$7 \quad \mathrm{O}$ Je Jong, Verordening omtrent het onderwijs 1815, art. 56, 314. 
Zie De Jong, $a w, 58,59$. Zie $\mathrm{C}$ de Ru, De strijd om het hoger onderwijs tijdens het ministerie-Kuyper, Kampen 1953, 16 (noot 33), voor regelingen. Zie Tweede Kamer, vergaderjaar 1984-1985, 19011, nrs 1-3, 10. Minister Deetman verwijst naar deze oude toezeggingen en schrijft dat de aanspraken van de gereformeerde kerken van recenter datum zijn; zij vinden hun grondslag in de Wet van 27 juni 1963, Stb 288. Pas in 1977 is een begin gemaakt met de subsidiëring van de ambtsopleiding van de christelijke gereformeerde kerken. "Een uitwerking van de grondslag in een concrete bekostigingsregeling is echter voor alle drie kerkgenootschappen nimmer tot stand gekomen, zij het dat daartoe wel pogingen zijn ondernomen. Ik wijs $u$ in dit verband op het rapport van een ambtelijke werkgroep dat in december 1980 is uitgebracht" (t.a.p.). Om tot een dergelijke regeling te komen stelt de minister een wijziging voor van de artikelen XIII en XIV van de Wet op het wetenschappelijke onderwijs (rijksbijdrage wetenschappelijk theologisch onderwijs).

C W van der Pot - A M Donner, Handboek van het Nederlandse Staatsrecht Zwolle: ${ }^{8} 1968,445$. De vrijheid van kerkelijke organisatie is in de grondwet van 1815 niet vastgelegd; de koning heeft zich daarmee diepgaand bemoeid door bij 7 januari 1816, een Algemeen Reglement voor het bestuur der Hervormde Kerk vast te stellen. Verder, zo leest men in Van der Pot - Donner, "werden nog reglementen voor de Israëlitische Kerk (!) en de Evangelisch Lutherse Kerk vastgesteld en vond ten aanzien van degenen, die zich rondom de omstreeks 1834 door de Hervormde kerk afgezette ambtsdragers als "afgescheidenen” organiseerden, een praktijk plaats, die als vervolging kon worden bestempeld" ( $p$ 448). Een gelegenheidswet bracht in 1853 meer afstand tot de overheid ( $p$ 448). In 1853 werd toegestemd in de wens om de rooms katholieke hiërarchie weer in te voeren, (p 449). Na 1848 trad de overheid terug in inmenging met de aangelegenheden der Hervormde Kerk; in 1866 werd een einde gemaakt aan het beheer van de goederen der Hervormde Kerk (p 449).

10 Zie De Geer, $a w, 236 v, 221 v, 225,251,267 v, 270$. Lutherse studenten in de theologie studeerden in Duitsland, tot in 1816 een seminarie werd gesticht, de facto als staatsinstelling; vanaf 1878 verkreeg de synode de bevoegdheid over de kweekschool. Zie H Brugmans e a (red), Gedenkboek van het atheneum en de universiteit van Amsterdam, I632-1932, Amsterdam 1932.

11 Zie $\mathrm{O}$ de Jong, "De wetgever van 1876 en de theologie", Ned Archief voor Kerkgeschiedenis - Nieuwe serie 48 (1967-8), 315v.

12 Huizinga, $a w, 1951,17$.

13 A de Lange, De verhouding tussen dogmatiek en godsdienstwetenschap binnen de theologie. Een onderzoek naar de onwikkeling van het theologiebegrip van J.H. Gunning Jr (1829-1905), Kampen 1987, 92v.

14 Hierbij valt te bedenken dat anderen erop aandrongen dat het gewone onderwijs christelijk zou zijn. Ook onder de orthodoxen waren er voorstanders van 
openbaar (niet-godsdienstig bepaald) onderwijs, omdat zij daarnaast hun eigen gereformeerd onderwijs wilden organiseren (zoals rooms katholieken eigen scholen konden inrichten). Deze kwestie speelde (vanaf ongeveer 1850) niet alleen voor het hoger onderwijs maar uiteraard op het brede vlak van het lager onderwijs.

15 Het doopsgezind seminarie werd in 1692 gesticht; na de dood van de eerste professor in 1706 werd het in 1735 heropend; tot 1811 werd het door de gemeente Amsterdam bekostigd, daarna door de Algemene Doopsgezinde Sociëteit. Zie Brugmans $a w, 269$.

$16 \mathrm{O} \mathrm{J}$ de Jong, $a \mathrm{w}, 316 \mathrm{v}$; Memorie van toelichting, in: Bijlagen Handelingen 1867-1868 (tweede zitting), 127v, 133. De tekst wordt ook uitvoerig geciteerd door A Kuyper in "Wet op Hooger Onderwijs", overgenomen uit de Heraut d d 21 januari 1970, in: A Kuyper, Ons program, Amsterdam '1879, 496v. Zie Kuypers commentaar, 497-501.

17 O J de Jong, $a w, 1879,317$; Memorie van toelichting, $a w$, art 145, 120. Deze werd in de HO-wet 1876 inderdaad geregeld, zie Kuyper over de vrijheid van hooger onderwijs, a $w, 1879,540-542$ (Heraut, 27 april 1876).

18 Bij Kuyper, $a w, 1879,497 v v$. (uit de Heraut, 21 januari 1870). Kuyper bespreekt beide wetsontwerpen. Hij geeft verre de voorkeur aan het ontwerpHeemskerk (kerkelijke seminaria bij universiteiten met rijksbekostiging) boven het ontwerp Fock (vrij theologisch wetenschappelijk onderwijs zonder dogmatiek). Een universiteit zonder theologie vindt hij geen universiteit.

19 Zie J van den Berg, “De vrijheid der Godgeleerde Wetenschap': kerk en theologische faculteit in de middenjaren van de negentiende eeuw", in: A Goudriaan et al (red), Feestbundel, uitgegeven ter gelegenheid van het 90-jarig bestaan van het Kerkhistorische gezelschap $S S S$, Leiden Theologisch Instituut 1992, 8.

20 Zie J Vree, "Van separatie naar integratie. De afgescheidenen en hun kerk in de Nederlandse samenleving”, in: Kranenborg en Stoker (red), Apeldoorn 1995, 170.

21 Kuyper liet allerlei nuances in de klassificering van theologen achterwege, zodat hij zich massief tegen "het modernisme" kon keren. Ook in wat aanvankelijk zijn eigen kring was bewerkte hij een breuk tussen de aanhangers van het Réveil en het (neo-)calvinisme, zie J Vree, "'Het Réveil' en 'het (neo-)calvinisme' in hun onderlinge samenhang (1856-1896)", in: Documentatieblad voor de Nederlandse Kerkgeschiedenis na 180016 (1993), 24-54.

22 Kuyper, $a w, 498$. Kuyper achtte het wetsontwerp Heemskerk 1868 onhaalbaar, omdat zowel de anti-revolutionairen als de liberalen zich hiertegen zouden keren. Kuypers beschrijving van de toestand in de kerk is eenzijdig, getuige 
bijvoorbeeld het feit dat in 1867 de mannelijke lidmaten van de kerk stemrecht verkregen; Kuyper zelf werd te Amsterdam beroepen en daar was hij bepaald niet de enige orthodoxe predikant.

$23 \quad$ Kuyper, a $w, 499$.

24 Kuyper, $a w, 540$ (uit de Heraut van 4 februari 1870).

25 Kuypers promotiebul staat afgebeeld in J de Bruijn, Abraham Kuyper - leven en werk in beeld, Amsterdam 1987, 51; Zie voor Bavincks studies J Veenhof, Tussen revelatie en inspiratie, Amsterdam 1968, 95, (noot 9).

26 J H Scholten, De Godgeleerdheid aan de Nederlandsche Hoogeschoolen. Volgens de wet op het Hoger Onderwijs, uitgevaardigd in 1876, Leiden 1876, $24 v v$.

27 Scholten, $a w, 26$.

28 G E Meuleman, De wet op het Hoger Onderwijs van 1876, Amsterdam 1982.

29 O J de Jong, $a w, 1967-1968,319$.

30 Zie Meuleman, $a w, 14$.

31 Meuleman, $a w, 13 v$. Zo ook de minister, ibidem 16.

32 Meuleman, $a w, 17 \mathrm{v}$.

33 Van Naamen, bij Meuleman, $a w, 15$.

34 G de Vries, bij Meuleman, aw, 18; De Jong, a w, 1967-1968, 328, citeert de Vries: "breng ... geloof en vertrouwen in de wetenschap over en gij doodt haar".

35 De Jong, $a w, 326$

36 De Jong, $a w, 327$. Handelingen eerste kamer 1875-6, 269-274.

37 De Jong, $a w, 328$.

38 Meuleman, $a w, 20$.

39 De Jong, $a w$, 324. In Het Academisch Statuut (Koninklijk Besluit 1921) met aantekeningen uitgegeven door $\mathrm{H}$ J Smidt, Alphen aan den Rijn, Samson 21932), 134v, worden genoemd: wijsgerige inleiding tot de godsdienstwetenschap, Hebreeuwsche taal en Israëlitische oudheden, voldoende kennis Nieuwtestamentisch Grieks en patristisch Latijn (propedeuse), en geschiedenis der 
godsdiensten in het algemeen, ethiek, uitlegging van geschriften des Ouden Testaments, overzicht van de Israëlitische letterkunde, godsdienst van Israël; uitlegging van geschriften des Nieuwen Testaments, overzicht van de Oudchristelijke letterkunde, geschiedenis van het Christendom, (p 2v en de toelichting op pp 133-136). Het Academisch Statuut uit 1960 bepaalt in art. 80/81 de volgende vakken: inleiding tot de theologische wetenschappen en tot de wijsbegeerte met Hebreeuwse taal- en letterkunde en met hellenistisch Grieks (propedeuse), en vervolgens: bijbelse vakken, geschiedenis van het christendom, ethiek en wijsbegeerte van de godsdienst, godsdienstwetenschappelijke vakken, sociaalwetenschappelijke vakken.

40 HO-wet, 1921, in: Smidt, a w, Titel II, Bijzonder Onderwijs, hoofdstuk II.

$41 \quad$ Aldus H J Smidt, a $w, 131$.

42 De Jong, $a w, 1967-1968,329$.

43 De Jong, $a w, 332$. Zie De Ru, $a w, 18$. Overigens zou men om tot een goed oordeel te komen, ook de ligging van de hoogleraren in de "staatsvakken" verdisconteren.

44 Scholten, $a w, 30$.

45 Meuleman, $a w, 13$.

46 A de Lange, a w, 1987, 91; J H Gunning, Het geloof der gemeente als theologische maatstaf des oordeels in de wijsbegeerte van den godsdienst, Utrecht $1890,31 \mathrm{vv}$. Gunning werd in 1878 tot kerkelijk hoogleraar te Utrecht benoemd, en later te Amsterdam en weer later te Leiden.

47 F E Daubanton, Ter Inleiding tor de Encyclopaedie der Theologie, Zwolle 1884, 21 .

48 Bavinck, De wetenschap der heilige godgeleerdheid, Kampen 1882, 5v.

49 De Ru, a w, 20. In de periode tussen 1880-1905 besprak men ook de mogelijkheid van staatsexamens voor alle universiteiten; in discussie was ook of de VU-studenten dubbel college moesten lopen.

50 De Ru, a w, 103. Stellingwerf, Kuyper en de VU, Kampen 1987, 293.

51 Bij 31.10.03 werd de oprichter van de Gereformeerde Bond in de Hervormde Kerk, Hugo Visscher, te Utrecht tot staatshoogleraar benoemd - waarmee Kuyper zowel de orthodoxie tegemoet kwam als een deel van de Gereformeerde Bond aan de anti-revolutionaire partij bond.

52 De Ru, a w, 127-132, vermeldt dat zijn bron aangeeft dat vrijzinnigen op deze vergadering het hoogste woord voerden. 
$53 \mathrm{Bij}$ verdere behandeling werd weer aangedrongen op verbetering van de theologische faculteiten van de openbare universiteiten, De Ru, $a w, 158 \mathrm{vv}$. Voor de rooms katholieke zuil was het wetsontwerp aanleiding om op 31 juli 1905 de Radboutstichting op te richten; men wilde beginnen met bijzonder leerstoelen en als men over voldoende katholieke hoogleraren zou beschikken een katholieke universiteit oprichten; de Keizer Karel Universiteit te Nijmegen werd geopend op 17 oktober 1923 (met rijkserkenning bij K.B. 9.10.23), De Ru, a w, 150v, 168-172.

54 Aan de Gemeentelijke Universiteit van Amsterdam zijn er kerkelijke hooglerarenvanwege de Luthersen en Doopsgezinden; te Leiden zijn er remonstrantse kerkelijke hoogleraren. In Utrecht bestaat een relatie met baptisten. In elk van deze gevallen geeft de kerkelijke opleiding een aanvulling op het staatsgedeelte van de theologie. De oprichting van de Universiteit van Amsterdam met haar theologische faculteit is een geval apart, waaraan wij hier voorbij moeten gaan.

$\mathrm{H}$ van Oyen, "Verantwoording", in: H van Oyen (red), Inleiding tot de Theologische Studie (samengesteld door de Faculteit der Godgeleerdheid aan de Rijksuniversiteit Groningen), Groningen 1946, 4v.

56 H Kraemer, De plaats van de godsdienstwetenschap in de Theologische Faculteit, Nijkerk 1959, 15.

57 H Berkhof, "De theologische faculteit, een nationaal cultuurprobleem", Wending 9 (1954), 25-37, zie 219-222; Berkhof laat ruimte voor onderscheiden verantwoordelijkheden tussen de kerk en de rijksuniversiteit, maar vergt wel een goede samenwerking waarin de kerkelijke vakken niet zijn achtergesteld, zie $\mathrm{H}$ Berkhof, "De strijd om een volwaardige theologische faculteit", Universiteit en Hogeschool, (maart 1979), 341-346.

58 W F Dankbaar \& O J de Jonge, "Woord vooraf", in: W F Dankbaar en O J de Jonge (reds), Inleiding tot de theologische studie, Groningen 1965, 9.

59 Dankbaar \& De Jonge, $a w, 9$.

60 A J Nijk en J S Weiland, “Over theologie en theologische studie”, Wending 24 (1969), 674.

61 Zie H Adriaanse, H A Klop, L Leetouwer, Het verschijnsel theologie. Over de wetenschappelijkheid van de theologie, Meppel 1987.

62 Van den Broek, "Het goed recht", in: F G M Broeyer en T van Willigenburg (red), Soror sorrorum. Opstellen over theologie en universiteit, Utrecht 1994, 16.

63 H Berkhof, "God voorwerp van wetenschap? I \& II", in: H Berkof, Bruggen en Bruggehoofden, Nijkerk 1981, 22-36, 208-215. 
64 A van de Beek, God kennen - met God leven, Nijkerk 1982.

$65 \mathrm{H}$ W de Knijff, "Theologie, wetenschap en universiteit", in: Broeyer en Van Willigenburg (red), $a w, 100-106$.

66 Ook staatsvakken als exegese en sociale wetenschappen (in de theologische faculteit) ontwikkelden zich in zekere mate en per instelling in wisselende mate in godsdienstwetenschappelijke richting. Een manier om dat kort aan te duiden is dat de bestudering van het Nieuwe Testament dan volgens eenzelfde methode verloopt als de bestudering van hindoeïstische, islamitische, humanistische en andere teksten.

67 P A H de Boer \& P Sj van Koningsveld, Honderd jaar "Uit Egypte", Leiden 1979. Leidse opstellen over de scheiding tussen kerk en staat aan de openbare theologische faculteit.

68 Door ingrijpen van staatssecretaris Klein, zie Berkhof, $a w, 344$. De staatssecretaris gaf naar Berkhofs oordeel een minimalistische uitleg aan de duplex ordo.

69 Zie A H Smuts en andere, Rapport van de Verkenningscommissie Godgeleerdheid, Den Haag 1989, I, 128.

70 De minister gaf zelf de aanzet tot het plan, zie Rapport Verkenningscommissie I, 129 noot 168 (aanwijzing d d 2.12.88). Het rapport van de Interkerkelijke Werkgroep Onderwijs en Onderzoek Theologie, "IWOOT" (in het voorjaar van 1989 ingesteld door de moderamina van de hervormde en gereformeerde synodes) werd door de gereformeerde synode besproken op 6 maart 1990 met besluitvorming op 9 oktober 1991. Zie voor de discussie over de verplaatsing van TUK naar Utrecht, in een gezamenlijk gebouw met de Katholieke Universiteit Utrecht en de Faculteit der Godgeleerdheid van Utrecht, de discussie op 7 september 1992, Acta van de Generale Synode van de Gereformeerde Kerken in Nederland, Mijdrecht 1991, art 141, 185-189, bijlage 22 in: Bijlagen bij de Acta, 184-192.

71 In verband hiermee moet de kerk alsvorens een persoon tot kerkelijk hoogleraar te benoemen, aan de Faculteit vragen of zij de kandidaat professorabel acht.

72 Zie het oordeel van de Verkenningscommissie Godgeleerdheid, I, 129.

73 De Knijff, $a w, 99$.

74 Zie H M Vroom, Inleiding tot de studie van religie (hoofdstuk 9), Heerlen 1989, en Geen andere goden (hoofdstuk 1), Kampen 1993.

75 Van den Broek, $a w, 22$.

76 Van den Broek, $a w, 24$ 